\title{
The Influence of Competency and Work-Job Fit on the Work-Engagement and Its Impact on The Employee's Performance of District Government
}

\author{
I Wayan Bagia ${ }^{1, *}$ Wayan Cipta $^{1}$ Fridayana Yudiaatmaja ${ }^{1}$ Komang Krisna Heryanda ${ }^{1}$ \\ ${ }^{I}$ Department of Management, Universitas Pendidikan Ganesha, Singaraja, Indonesia \\ *Corresponding author.Email: iwayan.bagia@yahoo.co.id
}

\begin{abstract}
This study goals to gain the rationalization finding which examined about the influence of: (1) competency, work-job fit and work-engagement on the employee's performance, (2) competency and work-job fit on the employee's workengagement, (3) competency and work-job healthy on the employee's overall performance and (4) district government employees in the province of Bali are extra productive when they are engaged in their work. In this study, we used a causal quantitative research approach. District government personnel are the center of attention of this research, which examines their competence, work-job fit, work-engagement, and performance. The populace of study had been civil servants who had been unfold in sevent district government in the Province of Bali. Structural random sampling and simple random sampling strategies had been used to select a random pattern of district governments and district authorities personnel for this study. Surveys and structured interviews have been used to acquire the data, which had been then analyzed using route analysis. The findings of the lookup show that (1) competency, work-job healthy and work-engagement have a vast influence on the employee's performance, (2) competency and work-job healthy have a large influence on the employee's work-engagement,(3) competency and work-job fit have a giant have an impact on on the employee's overall performance and (4) work-engagement has a giant have an effect on on the employee's overall performance in district government of Bali Province.
\end{abstract}

Keywords: Competency, Performance, Work-engagement, Work-job fit.

\section{INTRODUCTION}

The regency local government is a non-profit orgazation which it's tasks runs the functions of (1) giving service, (2) organizing, (3) developing, (4) representating, and (5) coordinating and planning $[1],[2]$. In carring out the functions of proving services to the community, it is necessary to integrated government as provider, employees as service providers, and community as service users [3]. The service provided to community can be both physical and administrative services [4]. In order for the implementation of this functions to run well, the government issued a law number 22 of 1999 concerning regional autonomy which provides an opportunity for loal government to organize regional autonomy in order to be more close services to the public who need it.Even thought, the reality showed that there are still many people who use public services who has impression of sympathetic and disappoited in the attitudes and behavior of district government employees that should a public servant, set an example and become the foundation of the region development are changed into community leaders. [5] poor quality of services can be tracked of many complaints that made by the public, especially relating to winded service and tend to be bureaucratic, high cost, there are additional levies, the behavior of the authrities is more like an official than a public servant, and discriminatory services.

This gives an indication of the presence of symptoms that employees districts government in the Province of Bali which is less clean, less authoritative, and less upholds its mission as servants of the state and society. [6] and [7] suspect that the cause of this negative image due to lack of government attention to the needs of society and on the other hand people's demands for quality, quantity and speed of service continue to experience an increase in line with the dynamic needs of the community. In addition, the implementation of regional autonomy that do not can be carried out smoothly due to limited aspects of human resources and institutions in the area [8]. 
The issue of the relatively low quality of services provided by employees of local government district in Bali Province based on observations in the field while allegedly because it is still relatively low level of employee inthe competency,work-job fit and workengagement. Even though according to [9] competecy, [10] work-job fit and [11] work-engagement affected employees performance in the public sector.

[12] in his research finding revealed that performance that is not optimal in local government employees of Buleleng district was indicated by the number of work done by the employees that not reached the target and did not balance the needs of the community, competence of employeesswho have not met the demands of the competencies required by the job, the physical and psychological work-engagement of employees in work is still relatively low, and the work-job fit of employees is not optimal. All of this will affect the low performance of district government employees in achieving organizational goals. This fact are be also supported by the findings of research conducted at [13], which shows that the productivity of civil servants in Indonesia is still very low, that is the average work productivity has just of $51.40 \%$. This fact gives an indication implicitly that the performance of government officials districts in the Province of Bali is still relatively low because the district government officials in Bali also included civil servants. Not achieving performance targets local government services as expected by the central government due to the still relatively low in competecy of human resources,work-job fit of employees in the organization [8], and work-engagement of employee in doing job [14]. All of this will affect the low level of the performance of services of government employees districts in the Province of Bali in achieving organizational goals

The results of the literature review found theoretically or hypothesized that competence and workjob fit adjustments interact with each other in shaping employee work-engagement [15], [16] and employee performance [17], [18]. If employee workengagement in their work increases, employee performance will also increase [19], [15], [20], [21]. Competence and work job-fit have a positive effect on employee work-engagement because employees at work feel the psychological meaning of work [22]. Likewise, competence, work job-fit and work-engagement together affect employee performance [9], [15]. This is supported by the results of previous empirical research from [23] which revealed that competence and work job-fit have a positive and significant effect on employee work-engagement. In addition, the research results of [24] also conclude that competency and work job-fit have a positive and significant effect on employee performance in the public service sector. On the other hand, [25] in their empirical research findings say that work-engagement has a positive and positive effect on performance.
This Problem indicated that the leadership of local government districts in the Province of Bali need empirical information about competency,work-job fit, work-engagementand employee performance and the effect of competency,work-job fit, work-engagementon performance accurately as consideration for taking decisions in improving, preventing, and solving the problem ofcompetency,work-job fit, work-engagement and performance who were be faced by employees. This is confirmed by [17] who said that the high of competency,work-job fit, work-engagement and performance to give a hint that the organization is well managed and fundamentally would result in an effective behavior management.

\section{LITERATURE REVIEW}

Ref [26] defined that an individual's competency is the capacity of the knowledge, skills and attitudes possessed by an employee that is relevant to the standard of work that will be carried out so as to carry out the work that has been designed for him both for now and in the future. Competency is the attitude and behavior of character or willingness and ability of a relatively stable when faced with a job that is formed from the synergy between the power intellectual, emotional, social and spiritual. [27]. This competencies are classified into four by Spencer \& Spenc, which include: (a) inteliectual, (b) emotional, (c) social, and (d) spiritual competency.

An individual's intellectual competency is a combination of traits, self-concepts, internal motivation and contextual knowledge capacity that is relatively stable when dealing with workplace problems. This is formed from the synergy between traits, self-concepts, internal motivation and contextual knowledge capacity. 'Intellectual competency' [27]. According to [28] Intellectual competency is internalized in the form of nine competencies, namely (a) the achievement, (b) the certainty of work, (c) initiative, (d) acquisition of information, (e) analytic thinking, (f) conceptual thinking, (g) membership of the practical, (h) linguistic capabilities, and (i) the ability of the narrative

In the workplace, emotional competence refers to a person's willingness and ability to master himself and understand the environment objectively and morally so that the pattern of emotions is relatively stable when faced with various problems. This is formed through a synergy of traits, self-concepts, internal motivation, and knowledge capacity of emotional competence [27]. Individual emotional competency internalized in the form of six levels of willingness and ability, namely (a) mutual understanding, (b) concern for the satisfaction of internal and external customers, (c) restraint, (d) confidence, (e) ability adapt, and (f) a commitment to the organization [29].

People's willingness and ability to build stable points of cooperation when confronted by workplace problems are examples of social competency. These points are 
formed by the synergy between traits, self-concept, internal motivation, and the capacity for contextual social knowledge [27]. Social competency of individuals is internalized in the form of seven disciplines (level of willingness and ability), namely (a) the effect and impact, (b) awareness of association, (c) establish a working relationship, (d) developing others, (e) directing subordinates, (f) teamwork, and (g) the leadership of the group [28].

One aspect of someone's consciousness is the ability to recognize and create new values based on wisdom that comes from sources other than the self or conscious thought. This is what it means to be spiritually competent [30]. On the other hand, [31] also revealed that spiritual intelligency is the ability to search and find the ultimate meaning with the help of intellectual and emotional intelligence and the ability to understand the value systems that apply to a person or group of people. According to [30] there are 9 characteristics of the competence development of non secular high, namely: (a) the capacity to be bendy or adaptive, (b) the degree of excessive self-awareness, (c) the capacity to confront and overcome suffering, (d) the capacity to confront and transcend the pain, (e) the fantastic of life inspired by means of the imaginative and prescient and values, (f) a reluctance to make unnecessary losses, $(\mathrm{g})$ the tendency to see matters holistically, (h) the tendency to constantly ask why, and (i) have the convenience to counter the convention. According to [32] there are eight internalization spiritual characteristics, namely (1) devoted and giving, (2) honest and reliable, (3) fair, (4) work together and unite, (5) fight and be steadfast, (6) friendly and compassionate, (7) thankful and grateful, and (8) is responsible; forgiving; and loving that will produce spiritual understanding, such as integrity or honesty, energy or passion, inspiration or initiative, wisdom and courage in decision-making.

Work-job fit (job-role fit) is the suitability felt by the employees between their self-concept with the suitability of their work roles in the organization which will result in a meaningful experience and work engagement. This is confirmed by [33] who say that "The concept of work-job fit is the perceived fit between individuals' self-concept and their role within the organization (work role fit) results in the experience. of meaningfulness and engagement". Research conducted by [34], [33] people who are able to express their beliefs and values openly in the workplace are more likely to have a meaningful life. Work is a calling for those who have a high level of role fit, so they will put in extra effort to complete tasks. [35]. The low level of work-job fit causes individuals to rearrange their work to get more meaning. According to [36] the suitability of employees' wor-job fit is measured by three indicators, including (1) vigor, (2) dedication and (3) absortion. In detail, these are three work-jobfit can be described as follows.

Vigor is a package of energy and mental resistance used by employees during work. There is a willingness to exert all efforts in solving problems and perseverance in the face of work difficulties. Enthusiasm that appears and is able to provide energy to help employees carry out all assigned tasks without complaining. This energy helps employees not to feel tired in completing the tasks assigned to them. Dedication is the feeling of being fully involved with employees when doing work, which is characterized by feelings of enthusiasm, meaning, full of inspiration, pride and likes challenges. The feeling of employees being in a good feeling condition to do the job. This relates to the arrival of inspiration and ideas to complete the work. Absortion is a feeling of full concentration and seriousness that arises in employees when doing work. Employees feel happy with their work This makes employees feel that time is running very fast at work, and it is difficult to separate themselves from work. Employees will feel immersed in their work and the benefits will be in the form of good quality work.

Employees who work hard at their jobs document greater tiers of work-engagement. It is an employee's commitment to the role and challenge for work each bodily and emotionally so that he considers the work performed very vital and has a sturdy faith that he is successful of finishing it [20]. Employees' full work attachment to work will result in the achievement of organizational goals and objectives. Psychological employee work attachment will create a sense of success which will increase employee self-esteem so that this condition will ultimately affect employee performance [20]. Besides that, there are experts or experts on human resource management and organizational behavior who view that workengagement is the degree to which employees know or identify the work they do, actively participate in it, and consider work performance as important for selfesteem. This is confirmed by [15], [21] the extent to which an employee knows or recognizes the work they do, actively participate in it, and considers their work performance to be important for their self-esteem.

There are seven characteristics of work engagement according to [37], including (1) spending time working and working continuously, (2) having a high concern for work and the company, (3) feeling satisfied with work, (4) having a commitment to work. who are high in career, profession, and organization, (5) keep absenteeism and turnover low by putting forth your best effort and (7) have high work motivation. In addition, [38] also reveals that there are five employee workengagements, namely (1) focusing on completing the current job and the next job, (2) feeling themselves as part of a team and something bigger than themselves. themselves, (3) feeling capable and not under pressure to make a leap at work, and (4) working with change and approaching challenges with mature behavior. On the other hand, [39] also said that the indicators of employees who have high work-engagement, namely (1) say consistent speak positive about the organization to co-workers, potential workers, and also to 
customers; (2) stay-have a desire to become a member of the organization where he works compared to the opportunity to work in other organizations; and (3) strive-give more time, effort and initiative to contribute to the organization's business success.

Performance is a record of the outcome resulting from a job function or specific activity during a specific time period [18]. There are three types of performance assessment different from each other, namely First, results-based performance evaluation, then behaviorbased, and finally judgment-based evaluation of performance [40]. The judgment-performance evaluation approach, the type of performance assessment that evaluates employees' performance based on descriptions of specific behaviors, will be used in this study to measure or assess workers performance. In other hand, [41], [40] says eight dimensions or criteria must be considered when evaluating the performance of employees based on the description of specific attitude, known as : (1) quantity of work, which is the amount of work completed within a specified time period; (2) quality of work, which is the quality of work achieved under the terms of suitability and readiness; (3) job knowledge, which is the extent of knowledge about jobs and skills; (4) creativity, which is the originality of ideas raised; There are a number of qualities that make a person a good team player, such as cooperation, dependability, initiative, and personal qualities such as personality, leadership, friendliness, and personal integration that all contribute to an individual's ability to perform well in the workplace.

\section{METHOD}

In this study, we used a causal quantitative research approach. District government employees are the focus of this study, which examines their competency, workjob fit, work engagement, and performance. In the province of Bali, the study participants were civil servants working in seventy district governments. There were two stages of random sampling in this study: random selection of district government and stratified random sampling of employees spread throughout the district government, both of which were carried out by using random sampling techniques. A questionnaire and structured interview techniques were used to collect the data, which were then analyzed using path analysis.

\section{RESULTS \& DISCUSSION}

\subsection{Results}

In the results presented research findings concerning the causal relationship competency, work-job fit and work-engagement on performance, competency and work-job fiton work-engagement, competency and work-job fit on performance and work-engagement on performance at the employe's district government in the Province of Bali as shown in Table 1.
The research results in Table 1 show that competency, work-job fit and work-engagement have a significant influence on performance at the workers district government in the Province of Bali because pvalue $=0.0000<\alpha=0.05$ with influence relationship to reach $88.81 \%$ and the rest it $11.19 \%$ had influenced by other variables relationship in the outside of study model. Another variables that strongly to influence performance arejob involvement, work motivation, job opportunities and quality of work life ([42].The contribution effect of competency, work-job fit and work-engagement on performance $78.87 \%$. Findings from this study indicated thatcompetency, work-job fit and work-engagement have play role together in the effort to support the formation of performance the workers districts government in the Province of Bali.

Competency and job fit are significant influences on work engagement at the district government in the province of Bali, where the p-value is 0.00000 .05 with influence relationship to reach $73 \%$ and the rest it $26 \%$ had influenced by other variables in the outside of the study model. Additionally, the compensation system, job satisfaction, and quality of life at work all have a significant impact on work-engagement [15]. The contribution effect of competencyand work-job fit on work-engagement $53.34 \%$.

According to the findings of this study, competency and work-job healthy play a sizable role in the effort to help the formation of work engagement in the districts government of Bali. P-values of 0 and 0.05 point out that competence and work-job suit have a significant have an effect on on the overall performance of district authorities personnel in the province of Bali. The affect relationship reaches 80.69 percent, whilst the relaxation of the 19.31 percent is influenced via different variables backyard of the find out about model. Job involvement, job satisfaction, and the first-rate of work lifestyles are extra elements that have a enormous have an effect on on work engagement [15]. The contribution effect of competency and work-job match on performance $65.11 \%$.

Findings from this find out about indicated that competency and work-job in shape have play function together in the effort to assist the formation of performance at the employee's districts authorities in the Province of Bali. Work-engagement has a large have an effect on on performance at the employe's district authorities in the Province of Bali because p-value = $0.0002<\alpha=0.05$ with have an effect on relationship to attain $39.90 \%$. Contribution impact of workengagement $15.92 \%$. Findings of this learn about confirmed that work-engagement has its very own position in the effort to assist the formation of overall performance the employee's districts authorities in the Province of Bali. 
Table 1. The Path Analysis Results of the Influence of Competency $\left(X_{1}\right)$, Work-Job Fit $\left(X_{2}\right)$ on the WorkEngagement $\left(\mathrm{X}_{3}\right)$ and Its Impact on the Performance $(\mathrm{Y})$ at workers District Government in the Province of Bali

\begin{tabular}{|c|c|c|c|c|l|}
\hline Parameter & Coefficient & $\mathrm{p}$-value & $\mathrm{A}$ & \multicolumn{1}{|c|}{ Decision } & \multicolumn{1}{|c|}{ Conclusion } \\
\hline $\mathrm{Rx}_{1} \mathrm{x}_{2}$ & 0.6200 & 0.0000 & 0.050 & Reject Ho & $\mathrm{x}_{1}$ and $\mathrm{x}_{2}$ are related \\
\hline $\mathrm{Ryx}_{1} \mathrm{x}_{2} \mathrm{x}_{3}$ & 0.8881 & 0.0000 & 0.050 & Reject Ho & $\mathrm{x}_{1}, \mathrm{x}_{2}$ and $\mathrm{x}_{3}$ have a significant influence on $\mathrm{y}$ \\
\hline $\mathrm{Rx}_{3} \mathrm{x}_{1} \mathrm{x}_{2}$ & 0.7304 & 0.0000 & 0.050 & Reject Ho & $\mathrm{x}_{1}$ and $\mathrm{x}_{2}$ have a significant influence on $\mathrm{x}_{3}$ \\
\hline $\mathrm{Ryx}_{1} \mathrm{x}_{2}$ & 0.8069 & 0.0000 & 0.050 & Reject Ho & $\mathrm{x}_{1}$ and $\mathrm{x}_{2}$ have a significant influence on $\mathrm{y}$ \\
\hline $\mathrm{Ryx}_{3}$ & 0.3990 & 0.0002 & 0.050 & Reject Ho & $\mathrm{x}_{3}$ has a significant influence on $\mathrm{y}$ \\
\hline
\end{tabular}

\subsection{Discussion}

The results of research showed that competency, work-job fit and work-engagement have a significant influence on performance at the workers district government in the Province of Bali. Findings from this study supporttheoretical statement of [15] who says that if competence, work-job fit and work-engagement increase, the employee performance will increase and emeperical study from [9], [43] who revealed that competency, work-job fit and work-engagement have significant influence on performance. The findings of this study gives implication that an increase in employee perormance at the district governments in the Province of Bali can be done by improving the competency work-job fit and work-engagement.

The research find results show that competency and workjob fit have a significant influence on workengagement at the workers district government in the Province of Bali. The results of this study confirm theoretical statement of [15] and [16] whorevealed that competensy and workjob fit interact with each in forming work-engagement. On the other hand, the study results also supported by emprical study of [22] and [23] who concludedthat competency and work-job fit have a significant influence on work-engagement. Competency and workjob fit can be improved by adjust the competency possessed by employees with existing work-job fit in the organization so that workers psychologically feel meaningful in doing work.

According to the findings of the research, a district government employee's competency and work-job fit have a significant impact on their performance. The results of this study confirm theoretical statement of [17], [18] who revealed that competensy and work-job fit interact with each in forming performance. On the other hand, the study results also supported the research findings emprical of [44], [25], [24] who concluded that competency and work-job fit have a significant influence on performance. Competency and work-job fit can be improved by adjust the competency possessed by employees with existing work-job fit in the organization so that employees psychologically feel meaningful in doing work.
The findings of the research results show that work-engagement has a significant effect on the performance of government officials districts in the Province of Bali. The results of this study confirm theoretical statement of [19], [20] who revealed that if the employees work-engagement inrease, the employee's performance willalso inrease. On the other hand, the study results also supported the research findings emprical of [43], [23] who concluded thatwork-engagement has a significant influence on employee performance. Work-engagement can be improved by providing opportunities for employees to develop employee job involvement, and statisfisian in organization. relationship with organization and always survive in the organization.

This study have several limitations, including (1) collecting data using questionnaires that the answer choices are closed so that respondets tend to select answers middle choces without reading it, as the result the data were collected is subjective, (2) an employee district government as a data source have a busy highin his job so hard contacted and slow in filling out the questionnaire, and (3) the results of this reserch new answered to relations of a quantitative manner, but not yet answer the reason why there have a significant relationship or contribution influence inthis study.

\section{CONCLUSION}

The following conclusions can be drawn from the previous section's results and discussion. Employee performance in the district government of Bali Province is strongly influenced by factors such as competence, work-job fit, and work engagement. Employee work engagement in the district government of Bali Province is strongly influenced by the employee's competence and work-job fit. In the district government of Bali Province, competence and work-job fit have a significant impact on employee performance. 4) Employee performance in the district government of Bali Province is significantly influenced by work-engagement. 
Based on the above discussion and conclusions can be presented some suggestions as follows. 1) Other researchers who are interested in examining the causal relationship between competency, work-job fit and work-engagement variables on performance are expected to develop this research model by including variable of job involvement, work motivation and organizational commitment as the independence variable and quality of work life as a second intervening variable which affects employee performance both directly and indirectly. The novelty in the next research lies in developing the construct of the variable quality of work life as an intervening variable. 2) For the district government in Bali Province had been expected to increasing employee's performance by focusing on the increassion of the competency, work-job fit and work-engagement because the results of the study indicate that these three variables have a significant effect on the performance of workers both directly and indirectly.

\section{REFERENCES}

[1] K. J. Davey, Financing Regional Government In Indonesian. New York: John Willey \& Sons, 2013.

[2] T. Supriatna, Government Administration System in the Region. Jakarta: Earth Literacy, 2014.

[3] I. Mochammad, Community Service Quality: Concept and Implementation. Jakarta: State Administration Institute, 2016.

[4] Munir, Public Service Management in Indonesia. Jakarta: Earth Akasara, 2012.

[5] A. Taringan, "Transformation of the New Governance Model as the Key Towards Optimizing Public Services in Indonesia," Indones. Entrep. Manag., no. 2, pp. 28-34, 2014.

[6] K. Wahyudin, State Administration Ethics. Jakarta: Rajawali Press, 2011.

[7] S. Soeharyono, "Human Resources Development of Government Apparatus," Dev. Manag., pp. 47-51, 2014.

[8] P. Tjiptoherijanto, "Professionalism of Civil Servants in the Era of Regional Autonomy," Dev. Manag., no. 36, pp. 5-8, 2013.

[9] J. A. Wagner, "Participation's Effect on Performance and Satisfaction: A Reconsideration of Research Evidence," $J$. Manage., vol. 21, no. 3, pp. 395-421, 2016.

[10] R. A. T. Noe, N. L. Moeller, and M. P. Fitzgerald, "A Meta-Analysis of The Relation of Job Characteristics to Performance.," J. Appl. Psychol., vol. 21, no. 3, pp. 280-289, 2015.

[11] S. D. R. Leong and J. Cote, "Explorating The Organizational Commitment-Performance
Linkage in Marketing: A Study of Life Insurance Sales people," J. Bus. Res., vol. 19, pp. 57-63, 2017.

[12] I. N. Tantra, Idenification of Factors That Cause Law of Work Motivation Employees District Government in Karangasem and Jembrana Regencies. 1997.

[13] Center of Population and Policy Studies, InterSector Labor Productivity Index in Indonesia. Yogyakarta: Gadjah Mada University, 2016.

[14] Indrawan, Understanding and Aspects ofWorkEngagement. University Of Psychology, 2012.

[15] S. P. Robbins, Theory of Organization: Structure, Design, and Applications. Interpreting Jusuf Udayana. Arcan Publishers, 2017.

[16] V. Anantaraman, Group Dynamics and Human Relations Organization Model. American Accounting Association, 2016.

[17] J. W. Newstrom and K. Davis, Organizational Behavior: Human Bahavior At Work. 11th Edition. McGraw-Hill, 2017.

[18] J. Wood, J. Wallace, R. M. Zeffane, Schrmerhorn, Hunt, and Osborn, Organizational Behavior A Global Perspective. John Wiley \& Sons Australia, 2018.

[19] J. R. Schermerhorn, J. J. Hunt, and R. N. Osborn, Managing Organizational Behavior. Fourth Edition. John Wiley \& Sons, 2014.

[20] M. Riadi, Definition, Dimensions, Aspects, and Characteristics of Work Engagement. 2018.

[21] K. Uma, Oranizational Behavior. Bandung: Pustaka Setia, 2010.

[22] S. K. Parker, "Enhancing Role Breadth SelfEfficacy: TheRole of Job Enrichment and Other Organizational Intervention," J. Appl. Psychol., vol. 9, no. 4, pp. 35-52, 2017.

[23] A. A. Fairus and J. E. Kurniawan, "The Effect of Competence and Work-Job fit Conformity on Work Engagement of Textile Company Employees," Psychopreneur J., vol. 2, 2018.

[24] J. E. Mathieu and D. Zajac, "A Review and Meta-Analysis of The Antecedents, Correlates, and Consequenses of Organizational Commitment," Psychol. Bull., vol. 94, pp. 171$183,2017$.

[25] N. J. Aranya, J. Pollock, and J. Amernic, "An Examination of Professional Commitment In Public Accounting," J. Account. Organ. Soc., vol. 6, pp. 271-280, 2016.

[26] A. Murray, N. Smith, and A. Millership, Understanding and Improving Team Performance. Australia: Griffin Press, 2018. 
[27] Spencer and Spencer, Competensy. The Dryden Press, 2009.

[28] Nahapiet and Ghoshal, "Social Capital, Intelectual Capital And The Organizational At Pantage," Acad. Manag. Rev., vol. 23, pp. 242266, 2013.

[29] D. Kristinawati and J. H. Tjakraatmadja, "BAGAIMANA KAPABILITAS DINAMIS DAN MANAJEMEN PENGETAHUAN BERPENGARUH KEPADA KINERJA PERUSAHAAN?: SEBUAH BANGUNAN MODEL KONSEPTUAL," Matrik J. Manajemen, Strateg. Bisnis dan Kewirausahaan, vol. 12, no. 2, pp. 99-110, 2018, doi: https://doi.org/10.24843/MATRIK:JMBK.2018. v12.i02.p02.

[30] Zohar and Marshall, "Quantitavive Study Of Emocional Intelligence And Its Inpect On The Peformance," J. Personal., vol. 66, pp. 525-554, 2018.

[31] W. Susilo, Motivasi Internal Dan Kecerdasan Emosional Karyawan. Bandung: PT Remaja Rosdakarya, 2017.

[32] Agustian, Human Resource Management. Bandung: PT. Remaja Rosdakaria, 2017.

[33] May, Strategic Human Resource Management. Thompson Learning, 2004.

[34] Kahn, The Social Psichology Of Organization. New York: Jhon Wiley, 1990.

[35] Dik and Duffy, The impact of work-job fit psycology essay. New York: John Willey \& Sons, 2008.

[36] Rothmann and Storm, Concept and Measurement of Work Role Conformity Indicators. PT Gramedia Indonesia, 2003.

[37] J. Cohen and P. Cohen, Applied Multiple Regression/Correlation Analysis for Behavioral Sciences. New York: Lawrence Erlbaum Association Inc., 2016.

[38] Federmen, The Indicator Measure of Work Engagement. Yogyakarta: Andi Offset, 2009.

[39] B. E. Becker, M. A. Huselid, and D. Ulrich, The Scorecard Linking People, Strategy, And Performance. Boston: Harvard Business School Press, 2001.

[40] F. C. Gomes, Human Resource Management. Yogyakarta: Andi Offset, 2016.

[41] J. M. Ivancevich, Human Resource Management. Eighth Edition. McGraw-Hill, 2017.

[42] R. Kreitner and A. Kinicki, Organizational Behavior. Fifth Edition. McGraw-Hill, 2018.
[43] A. S. DeNisi and A. N. Kluger, "Feedback effectiveness: Can 360-degree appraisals be improved?," Acad. Manag. Perspect., vol. 14, no. 1, pp. 129-139, 2000, doi: DOI:10.5465/AME.2000.2909845.

[44] K. Ferris, "Organizational Commitment and Performance in A Professional Accounting Firm," Account. Organ. Soc., vol. 6, no. 4, pp. 317-325, 2015. 